\title{
Ethno-religious conflict and sustainable development in Nigeria
}

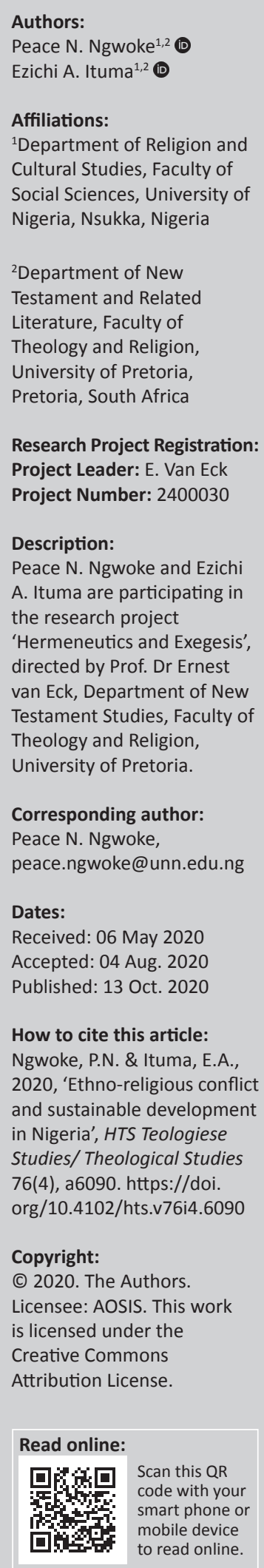

This article examines the extent to which ethno-religious conflicts have affected sustainable development in Nigeria. The destruction of lives and property by reckless ethnic and religious extremists has been a challenging key factor to sustainable development in Nigeria. This article aims to reflect on the ethno-religious conflicts in Nigeria from an epistemological point of view, ascertain the major causes of these conflicts and seek solutions to address the root causes. The article concludes that religious intolerance among Nigerians from different religious groups is the result of the misinterpretation of religious teachings of the leaders of terrorist groups to their followers and that ethno-religious conflicts in Nigeria affect sustainable development as they lead to loss of lives and destruction of property, among others. It is also indicated that the effects of ethno-religious conflicts in Nigeria lead to an increase in the unemployment rate, withdrawal of foreign investments and education imbalance. The article concludes by arguing that ethnicity and religious crises are unhealthy for the nation's sustainable development and that no price paid in the direction of resolving these conflicts can be considered to be too much. It is recommended that religious leaders form the minds of Nigerians with the teaching of love and peace, as it is proclaimed in their various religious books and beliefs.

Contribution: This article brought to light the major factors instigating continuous ethnoreligious conflict in Nigeria that has led to much social unrest. Theological reflection of the influence of religion in promoting peaceful coexisting environment was analysed. This work would be of immense benefit to religious bodies, government, civil society and students.

Keywords: Conflict; Ethnic identity; Religious identity; Intolerance; Marginalisation and sustainable development.

\section{Introduction}

Conflict, as generally known, breaks out from a disagreement, controversy or quarrel between two or more people or groups of people. When such a disagreement, controversy or quarrel is not resolved or managed, it escalates to a disordered state where violent actions manifest. Alegbeleye (2014:142), in his work, describes conflict as 'a situation or condition of disharmony in an interactional process'. Nigeria is presently witnessing conflicts of varying scales and intensities in different parts of the country. This has led to much social unrest, which has taken a toll on humanity in terms of deaths, displacements, destruction of lives and property, disruption of economic and social activities, poverty, insecurity and so on. Conflict with its multidimensional consequences has been identified by scholars as an obstacle to progress, economic growth, political stability and overall socio-economic development (Edewor, Aluko \& Folarin 2014; Polachek \& Sevastianova 2012; Ray \& Esteban 2017).

The consistent killing and destruction of property, as a result of ethnic and religious clashes in Nigeria, are dominated by Fulani herdsmen, who are nomadic cattle grazers but are known for their militant actions in their host communities, and the Boko Haram group, comprising Islamic fundamentalist militants. The governor of Borno State, Mr Kashim Shettima, said that 'the insurgency has led to the deaths of almost 100,000 persons, based on estimates by community leaders in the State over the years' (Tukur 2018:1). From the assertion of the governor of Borno State, one would agree that the incessant killing by Boko Haram has become an affront to humanity. In recent times, the Fulani herdsmen have become a threat to their host communities, with several incidents of attacks they have carried out against their host communities. However, most of the Boko Haram or Fulani herdsman attacks were linked to ethnic differences or religious intolerance, as some of the conflicts were ethnically or religiously driven (Salawu 2010). Subsequently, during the ethnic or religious conflict outbreak in Northern Nigeria, the Igbo ethnic group (predominantly Christians in south-eastern Nigeria) were the major victims of mass killings.

Note: Special Collection entitled Africa Platform for NT Scholars, sub-edited by Ernest van Eck (UP). 
Moreover, the Igbos, in order to avenge their lost brothers and sisters, quickly organised a retaliatory killing of Muslims residing in south-eastern Nigeria. Hence, in the event of these conflicts, lives were lost, people were displaced from their homes, businesses were disrupted and people's goods were destroyed in most cases.

The Global Terrorism Index (2019) shows that, in 2018 alone, more than 2000 people lost their lives, whilst 300000 people were displaced through the insurgence of Fulani herdsmen and Boko Haram in Nigeria. It is worrisome to note that the rate of killings through various insurgency attacks has been on the rise. This is evident in the Global Terrorism Index (2019) report, which reveals that Nigeria's terrorism index rose from 36th to 3rd from 2002 to 2018, with total recorded deaths of 22415 people. The terrorist attacks also involved the destruction of property and displacement of people, which goes a long way in destabilising the economy of the nation, as money that is meant for the development of the country is channelled to rebuilding the destroyed environments and property and the rehabilitation of displaced people. As a result of all these conflicts, sustainable development in Nigeria appears to be an unachievable goal.

In Nigeria, so much has gone into nation-building, but at the end of the day, what would have contributed to sustainable development is destroyed as a result of excessive ethnoreligious conflicts. Thus, research literature by various authors has explored numerous strategies and methods to stop these ethno-religious conflicts. Most authors agree that discouraging all forms of discrimination, neglect, favouritism, nepotism, marginalisation and tribalism in sharing of public positions, dealing with religious issues and other issues in all spheres in the nation would help curb the ethno-religious conflict tension in Nigeria (Alegbeleye 2014; Canci \& Odukoya 2016; Omotosho 2003; Onah, Diara \& Uroko 2017; Osunyikanmi \& Sapele 2019; Salawu 2010). Furthermore, other authors claim that religious tolerance is a key factor that will defuse religious conflicts (Onah et al. 2017; Osunyikanmi \& Sapele 2019). However, Salawu (2010:351) argues that providing 'adequate and effective security in each state that should be able to respond promptly to any insurgence of ethno-religious crisis anywhere at any time' will curb the ethno-religious conflicts. Onah et al. (2017:66) take a contrary position suggesting that as 'adherents of different religions imbibe the moral teachings of religions such as love for one another', peaceful coexistence will be achieved. However, they did not show how this religious teaching would influence society in order to instil the muchneeded social change and norms in the people.

Therefore, the goal of this article is to examine how religion can be used to influence Nigerian society in order to instil the much-needed social change and norms in people, which will make them drop their old violent norms and embrace new ones that will ignite peaceful coexistence amongst themselves. To achieve this objective, this research will investigate some incidents of ethno-religious conflicts, their causes and the threat they pose to the sustainable development of Nigeria.
Thus, the research leaves open an important question: are there factors that instigate ethno-religious conflicts in Nigeria? Because a majority of Nigerians are religious faithful, how can the various religious bodies contribute meaningfully to manage the situation and bring about a lasting solution that will result in the much-needed peace? These issues are the main thrust of this study.

\section{Major ethno-religious conflicts in Nigeria}

It is important to state from the beginning that the various ethno-religious conflicts that have swept across this country in the past three decades are too numerous to outline and analyse in one study. Thus, this article highlights some of the major conflicts in Nigeria.

\section{The Maitatsine crises}

The Maitatsine crises broke out in the northern part of Nigeria in 1980 and lasted until 1985, when they were suppressed by the Nigerian military forces. The crises were one of the major religious crises in Nigeria that claimed over 10000 lives (Falola cited in Aghedo 2014). Their main goal was to promote the Islamic religion within Northern Nigeria and preach against modernisation, such as the use of television, radio and car; Western education and so on. According to Okwueze (2003:145), the Maitatsine crises were led by an Islamic cleric Mohammed Marwa Maitatsine, 'who had his infamous kingdom in the heart of Kano with a fanatical band of more than 10,000 followers'. The Maitatsine group was known for its exhibition of religious intolerance towards anyone who did not share the same belief. The group's name was derived from the name of the leader Maitatsine, which is a Hausa word meaning 'the one who curses' because of his curse-laden public speeches; due to its religious intolerance, the group fought against the Nigerian government and the Nigerian state (Aghedo 2014). Thus, the group fought and killed people who had opinions that differed from their belief, as they considered such people unbelievers, tagging them as infidels.

However, it is worthy to note that this group drew its members from the poor, uneducated and unemployed, who were economically, socially and politically marginalised. Thus, Ikenga-Metuh (1994) agrees with this line of thought when he recognises that the social, political and economic dimensions of the Maitatsine can be linked to marginalisation, as the people involved were mostly of the marginalised groups.

\section{Kano religious uprising}

The religious crises in Kano State started with the Maitatsine religious violence, which included burning of mosques and churches and killing Christians. Shortly after the menace of the Maitatsine riots from 1980 to 1985, this uprising was occasioned by the violent reaction of Muslim youth against the hosting of a Christian crusade, where a notable German Evangelist, Reinhard Bonnke, and some American preachers were to visit Kano. It started as a protest by the Muslims against the hosting 
of the planned crusade, to stop the crusade from being held, but finally led to attacks on the churches, businesses and houses in Sabon Gari town, Kano State (Best \& Rakodi 2011). The attack claimed many lives and properties.

\section{Boko Haram insurgence}

The Boko Haram group emerged as an Islamic group and ignited ethno-religious conflict in Nigeria with its ideology and advocacy against Western education and culture. According to Idowu (2015), Boko Haram started as a fundamental Islamic sect to help the government of the Northern Region achieve its intention of implementing sharia law across the northern states. Their activities have led to the killings of thousands of people, the destruction of property and the displacement of people from their homes and businesses, and they have created the threat of insecurity in the entire country.

The Boko Haram group has claimed responsibility for many killings, kidnappings and multiple bombings in Nigeria, such as (Alegbeleye 2014):

[T]he Christmas bombing of a Catholic church in Madala, Niger State in 2010 and the bombing of the United Nations House in Abuja, attacks on prisons, police stations and military formation in Jaji, Kaduna State, the kidnapping of a French family of seven, the Shettima of Borno. (p. 143)

In recent times, Boko Haram has focused most of its insurgent attacks on the Christian religious group in Nigeria. One of the recent attacks by Boko Haram on the Christian religious group included the killing of the Christian Association of Nigeria (CAN) chairman, Reverend Lawan Andimi, in Michika Local Government Area, Adamawa State, whom they abducted when they attacked the city on Thursday, 02 January 2020 (Odunsi 2020). They also forced the Christian adherents they captured to denounce their religion and join the Islamic religious group or face consequent action from them. Such action was exhibited to one of the captured Chibok girls, who refused to denounce her religion and accept the Islamic religion; they released others but held her back (Eyoboka 2020). Certainly, the various operational attacks by Boko Haram buttress the fact that their attacks are based on intolerance towards other religious groups.

The report from the Global Terrorism Index (2019) reveals that 22415 people have been killed by Boko Haram since 2002. Today, the Boko Haram insurgence in Nigeria is synonymous with destruction, which is antidevelopment.

\section{Fulani herdsmen upheavals}

The Fulani herdsmen's clash with their host community has been recorded in all strata of the country. According to Aliyu, Ikedinma and Akinwande (2018), the clash of Fulani herdsmen with farmers in their host community date back to 2012 with the killing of one Mr Benjamin Chegue, Director of Personnel Management in Isoko North Local Government Area, Delta State. Since then, the spate of killings linked to these clashes has continued across the entire northern and southern zones of the country.

Most of these clashes started in the northern part of the country. In the north-central part of the country, some of the incidents included a Fulani herdsmen attack in Agatu, in which they burned the Inoli, Ologba, Olegeje, Olegogboche, Olegede, Adana, Inminy and Abugbe communities on 29 February 2013 (Ndujihe 2018). Others include the attack on civilians in Aguta Local Government Area on 20 February 2016, killing 500 and displacing 7000 people (Ndujihe 2018).

In the north-east states, one recent incident is the attack on the people of Jalingo, the state capital of Taraba, by the Fulani herdsmen on 15 June 2019 as reported by a resident of Kasuwan Bera, who stated that Jalingo was on fire and that the Fulani herdsmen were on the rampage firing gunshots randomly in the village (Vanguard 2019). The following week, there was another attack by the same Fulani herdsmen on the residents of Tudiri and Janibanibu communities in Ardo Kola Local Government Area in Taraba State on 16 and 17 June, killing 10 people (Femi Bolaji 2019).

In the north-west states, in one recent attack, over 10 communities in the Chikun Local Government Area of Kaduna State were invaded on 06 January 2020 by the Fulani herdsmen, who killed not less than 35 persons and abducted over 58 persons; another attack in the early days of March 2020 led to the death of 51 persons (Hassan 2020).

The southern region of the nation has not been left out, as they have also received their share of attacks from the Fulani herdsmen. In the south-west states, one current conflict between the Fulani herdsmen and their host community resulted in an attack by the Fulani herdsmen in March 2020. In the attack, the Fulani herdsmen killed three persons, including a rice farmer and his son, who were reportedly murdered on their farm by herdsmen in the community of Arimogija, Ose Council Area, Ondo State (Johnson 2020).

In the south-south states, a recent incident in Delta State claimed 14 lives. According to Okafor and Neme (2020), the crisis began on Thursday, 13 February 2020, when herdsmen arrived at Uwheru community, in Ughelli North Local Council, Delta State, with a large number of cows and destroyed farms; the youth mobilised and warded them off their farms, but the herdsmen regrouped, armed themselves and returned to the community and started attacking them.

In the south-east states, an incident occurred in the Nimbo community in Uzo-Uwani Local Government Area, Enugu State, in the early hours of Monday, 25 April 2016, resulting in the death of over 40 persons, burning of 11 houses including a Catholic church, destruction of vehicles and motorcycles and slaughter of domestic animals (Mamah et al. 2016).

The rampage killings of people and destruction of farmland and property by the Fulani herdsmen have become an issue 
of great concern to the unity and development of Nigeria. The increase in killings by the Fulani herdsmen is alarming and has caused the death of 3641 people in 3 years, with $57 \%$ of these deaths occurring in 2018 (Amnesty International 2018). Thus, this explains why the Fulani herdsmen are rated the fourth deadliest militant group in the world (Global Terrorism Index 2019).

\section{Causes of ethno-religious conflicts}

Ethno-religious conflicts have taken a historical toll in Nigeria. They manifest in different patterns and have led to the destruction of lives, displacement of people and destruction of property. The experience of these ethnoreligious conflicts has affected Nigeria's sustainable development. Some authors have attributed the cause of these conflicts to various factors ranging from marginalisation and competition for economic and political spaces to sharing of land, economic and mineral resources (Alegbeleye 2014; Canci \& Odukoya 2016; Omotosho 2003; Onah et al. 2017; Salawu 2010).

Furthermore, one would agree with Alegbeleye (2014:144), who posits that 'the high rate of unemployment in the country coupled with social injustice and inequality are also causes of these conflicts'. Just as in the words of the Holy Bible, 'idle hands are the devil's workshop' (Pr 16:27 TLB), most jobless Nigerians have become tools in the hands of hoodlums, who pay them to carry out violent attacks.

The conflict between the Fulani herdsmen and their host community is attributed to the scarcity of resources such as land, water and pasture. This scarcity has led to competition for resources, which is the cause of the current ethnic conflict in Nigeria (Amnesty International 2018). This has led to repeated bloody clashes between the Fulani herdsmen and their host community.

The failure of the social control institution in Nigeria can also be seen as a contributor to the various ethno-religious conflicts witnessed in Nigeria today. This is evidenced in the research by Canci and Odukoya (2016), who posit that the:

[A]bsence of vehicles of social control that were characteristic of traditional African societies, such as kinship, religious and political systems concerned with the well-being of the community, has led to the escalation of ethno-religious conflicts. (p. 103)

From the study of Canci and Odukoya, one would agree that institutions such as traditional rulership, which is referred to as Oba or Onii in 'the south-west, Obi or Eze in the south-east and Emir or Sultan in the northern parts of Nigeria, have been actively functioning as a social control institution that controls their ethnic groups to maintain peace within their people. They also come into dialogue when there is an outbreak of conflict between people from different communities. In an African society, the traditional ruler controls his subjects, who are necessarily people with a common identity. Also, in the religious and political systems, there is always a religious leader and a political leader, who lead the religious and political groups, respectively. Hence, their subjects obey their commands. Therefore, one would agree that if all these social institutions actively performed their functions, they would be able to maintain peaceful coexistence amongst their subjects (ethnic group or religious group) and other groups.

The cause of conflicts such as the Maitatsine riots, Kano religious crises, Jos crises and Boko Haram can be linked to religious intolerance. According to Onah et al. (2017), religious intolerance was the major factor instigating violence in Nigeria. They cited cases ranging from the Maitatsine riots in 1980 to the Boko Haram uprising. The Maitatsine riots manifested because of the violent attacks from Mohammed Marwa's (the group leader) adherents on other religious groups. Onah et al.'s (2017) research reveals that the Kafanchan tumult of March 1987 started in the College of Education over a crusade being organised by Christian students and spread to Funtua, Kaduna Metropolis, Zaria and environs. Religious intolerance is also seen in the attacks of Boko Haram, which exhibit religious intolerance against the Christian group by killing Christians, destroying their churches and even raping their women, claiming that it is jizya, which means a tax paid by Christians under Islamic law. The lack of a genuine desire to tolerate people from a religious group one does not believe in or belong to has made it difficult for people from different ethnic and religious groups to understand each other's belief and culture (Omotosho 2003). Hence, this leaves room for the wrong perspective and behaviour towards each other.

From the assessment of the aforementioned causes of ethno-religious conflict in Nigeria, one can deduce that the religious intolerance that is seen among Nigerians from different religious groups is the result of misinterpretation of religious teachings by the leaders of terrorist groups to their followers.

\section{Effects of ethno-religious conflicts on sustainable development}

Nigeria, as a country, has been battling with the challenges of ethnic and religious conflict, which is capable of disintegrating the fabric of sustainable development. The conflict has led to the loss of many lives, destruction of property and displacement of people from their businesses and homes. Therefore, this article discusses some of the effects of ethnoreligious conflict in Nigeria.

\section{Food production and poverty effect}

The ethno-religious conflict in Nigeria has upset the agricultural sector, especially the crises involving the farmers and Fulani herdsmen, due to which farms worth billions of naira have been destroyed. Also, the research work of Idowu (2015) shows that more than 1.5 million people, mostly farmers, have fled their homes in the face of several ethno- 
religious conflicts in Nigeria. Certainly, this will affect food production, thus resulting in shortages. These shortages lead to an increase in food prices, thus making food unaffordable for some people because of the increased cost. This also means that some people are forced into poverty because of their losses, from the destruction of their business or farmland.

\section{Educational imbalance}

Education is a foundation for sustainable development. However, conflicts have far-reaching implications on education, with the destruction of school structures where the teaching/learning exercises take place. They also affect the people, including the staff and students; in a state with ongoing conflicts, the learning environment would not be conducive to teaching/learning. According to Adebayo (2010), the ethno-religious crisis in the northern part of Nigeria is destroying education, which is a very important sector for driving sustainable development, as the instability of education from various cases of ethno-religious conflict has led to brain drain. Subsequently, education is affected as the nation strives to manage the conflicts by declaring a state of emergency, which leads to temporary closure of schools within the conflict area. In some cases, school buildings and other infrastructure are destroyed in the face of the conflict. One of the obvious consequences of the conflicts in education is that the curriculum designed to graduate students in a stipulated number of years faces the challenge of being disrupted, hence leading to situations where students may spend more years in a 4-year programme. Thus, educational programmes in the country have seriously been affected by incidences of ethno-religious conflict in Nigeria. Therefore, one would agree that these impending effects of the conflict have contributed to the reason why some youths have become school dropouts.

\section{The scourge of unemployment}

The scourge of unemployment has been a monster plaguing sustainable development from the inception of independence. The increase in the population of the country does not correspond to the available employment opportunities. According to the National Bureau of Statistics (2020), in their 2018 third-quarter labour report, $23.1 \%$ of Nigerians were unemployed. This report is worrisome, as it indicates that unemployment is increasing in Nigeria. It is a sorry situation as some people who put in the effort to set up a small-scale business or farm end up losing their business or farm to the destructive attacks by hoodlums, thereby forcing some people out of employment and setting the economy of the nation backwards. There is no doubt that the various ethnoreligious conflicts have contributed to the unemployed state of some Nigerians, as people whose place of work has been destroyed join the unemployed. Many displaced people have also been forced into unemployment as they are forced out of their communities, either by the Fulani herdsman or Boko Haram attacks. It is worrisome to note that some of the affected people do not have any other source of income, and this further leads them to join the militant groups, who promise to pay them, thereby leading to an increase in the crime rate. Supporting this point, Onuoha (2012) posits that poverty and unemployment have forced some of them into secret cults, armed robbery gangs, prostitution and infant soldiers. It is a bleak situation; people end up losing their businesses or farms to destructive attacks by hoodlums, alongside the government infrastructure, thereby setting the economy of the nation backwards.

As established, the effect of ethno-religious conflicts in Nigeria is quite alarming, with hundreds of lives and properties lost and many people forced to escape their communities, abandoning their farms and businesses and being added to the number of jobless citizens in the labour market, all resulting from the ethno-religious crises, which have indeed affected Nigeria's sustainable development.

\section{The influence of religion}

The relationship between religion and society can be applied to Nigerian society based on the fact that the majority of Nigerians are religious faithful. The various religious bodies draw their members from all segments of the population in Nigeria and know the local situation well. Also, the religious bodies are rooted in the community, with a presence across entire states, even down to remote communities. Hence, religion serves the whole society, which includes people from various families, communities, and those who work in government and private parastatal (Oladipo 2000). With this advantage, religion has the potential strength to effectively mobilise and influence the people of various communities in Nigeria. Therefore, as religion serves the people, it will provide 'social cohesion to help maintain social solidarity through shared rituals and beliefs, social control to enforce religious-based morals and norms to help maintain conformity and control in the society', as proposed for the function of religion in the society (Durkheim cited in NziokiMunyao, MuemaMwania \& Mwinzi 2017:31).

From the above submission of Durkheim, one can deduce that religion has the power to influence the value system of people in any given society. Thus, religion, through the teachings of norms and values stipulated in their religious book and beliefs, influences individuals who are affiliated to them (their adherents) and adhere to their teachings. Arguing in the same direction, Osunyikanmi and Sapele (2019) posit that religion is undoubtedly a major influence in the world today.

From what we can deduce of the major causes of these conflicts, ranging from intolerance to marginalisation to greed, religion has played a great role in influencing them. However, the research argues that religious teachings condemn the killing of the innocent, greed, corruption and doing evil. Thus, in line with this, religion can be used to form the minds of Nigerians with the teachings of love and peace, as in the teachings of various religious bodies. This is supported by Okwueze (2003), who posits that every 
religious group maintains the teaching of peace with God and with fellow human beings. Therefore, with these teachings, religion can influence people to live in harmony. Other teachings, as seen in the sacred book, and teachings of the three major religions (traditional religion, Christianity and Islam) in Nigeria that influence people to live in harmony amongst themselves include love one another, desist from doing evil, avoid killing a fellow human being and so on.

Christian religious groups that base their teachings on the teachings and life of Jesus Christ uphold key fundamental principles such as love one another, as instructed by Jesus Christ (Jn 13:32-26 KJV): 'By this shall all men know that ye are my disciples if ye have love one to another'. Living in peace with everybody is another fundamental teaching of Christian religious groups as written in Hebrews 12:14 (KJV): 'follow peace with all men and holiness without which no man shall see the Lord'. Moreover, the teachings discourage doing anything bad or evil to anyone and maintain doing good to all humans, as written in 1 Thessalonians 5:15 (KJV): 'See that none render evil for evil unto any man; but ever follow that which is good, both among yourselves, and to all men'.

Along the same line, the Islamic religious group takes their teachings from the life and teachings of Muhammed, which is documented in their sacred book (the Holy Qu'ran). The Qu'ran encourages Muslims to do that which is halal [permitted], to refrain from that which is haram [evil], to do righteous good deeds and to recommend one another to the truth (Al-Ma'ruf), which Allah has ordained. The Qur'an emphasises the abhorrence of everything evil (haram) (Danjibo cited in Faleye 2013).

The same goes for the indigenous religious groups (ATR), who hold instant justice against wrongdoing. The ATR is based on fundamental teachings of just treatment of every human, love, hospitality and abhorrence of any action that leads to the killing of a fellow human being, which they regard as Igbuochu [abomination]. Thus, such an action is meant to incur the wrath of the god against the perpetrator. Also, the teachings and practices of ATR include 'values and morals which deal with the ideas that defend or sustain the life of the people in their relationship with one another and the world around them' (Ekeopara \& Ekpenyong 2016:20). Therefore, from aforementioned submissions, one can agree that because the influence of religion on society has increased to the extent that its presence is visible everywhere (Herbert 2017), religion can efficiently and effectively contribute immensely to the actualisation of ending the ethno-religious conflict in Nigeria.

It is worthy to note that in Nigeria today, religion has also been used to promote conflict. This is evident in the work of Ajayi (2009), who posits that religion is used by Nigerian politicians to cause division and instigate violence. This situation plays out as politicians use religious sentiments to psychologically exploit the people to gain political positions.
However, the positive role of religion can mitigate these negative roles of religion. This can be achieved by influencing and forming people's minds with the fundamental teachings of various religious bodies, which anchor on treating every human justly, loving every human and showing hospitality. In support of this point, Ituma, Ukeachusim and Illechukwu (2013) argue that when people's hearts and minds are rightly guided, they would live on the high tendencies of proper behaviour. Therefore, with the habits of treating every human justly, loving every human and showing hospitality, the conflict in society will fade away.

\section{Recommendations}

This study shares somes recommendations to actualise the goal of ending the ethno-religious conflicts in Nigeria:

1. Religious leaders should form the minds of Nigerians with the teachings of love and peace as in their various religious books and beliefs. This can be achieved through their teachings at religious gatherings.

2. Courses that will help in forming and educating people's minds on love and peaceful coexistence in Nigeria should be included in the Nigerian educational curriculum. This can be achieved by setting up a committee comprising members from the Nigerian Educational Research and Development Council (NERDC), National Universities Commission (NUC) and Federal Ministry of Education (FME) to ensure that ethics are included in the curriculum from primary education level to tertiary level, both as a course and also as a department.

3. Religious groups in Nigeria should put in measures to caution or punish their adherents in any action that promotes violence. The religious groups should also set up a committee that will monitor and counsel adherents who propagate violence or engage in violence.

4. Religious leaders should discourage and condemn any act of intolerance or violence from their adherents towards other religious groups.

5. Seminars, conferences and workshops that focus on promoting the teachings of love and peace should be organised by various religious bodies in Nigeria, where trained religious leaders, traditional rulers, scholars, counsellors and other professionals would assist in propagating an anti-violence campaign.

6. Finally, the Nigerian government should implement the principle of power-sharing at both the federal and state levels as surrogates for ethno-religious identities. The government should make copious efforts to disassociate itself from any form of inclination to any religion because it is a secular state.

\section{Conclusion}

It has been established from the findings of this study that the rate at which ethno-religious conflict thrives in Nigeria, with its resultant effects such as threats to lives and property, displacement of people, destruction of existing infrastructure, impeding of business activities and discouragement of investors, it hinders the sustainable development of Nigeria. 
Therefore, priority should be given by all stakeholders for measures that will foster peaceful coexistence amongst the different ethnic and religious groups. Because the majority of Nigerians identify with a religion and our leaders are sworn into office with a religious oath, this article therefore concludes that the religious leaders should take key responsibility of driving this project as an agent of social change. This can be achieved by forming the minds of the people with the religious teachings of love and peace, which the three major religious bodies in Nigeria teach. This will eliminate any form of marginalisation against any group and will then give every citizen a sense of being a true citizen of the country. Therefore, love and peace will thrive above personal interest, and the country will thrive in all areas. Then, sustainable development across all parts of Nigeria will be achieved.

\section{Acknowledgements}

The authors thank the people who assisted them in the proofreading and editing of this research article.

\section{Competing interests}

The authors declare that they have no financial or personal relationships that may have inappropriately influenced them in writing this research article.

\section{Authors' contributions}

P.N.N. and E.A.I. contributed to the design and implementation of the research, analysis of the results and writing of the article.

\section{Ethical considerations}

This article followed all ethical standards for research without direct contact with human or animal subjects.

\section{Funding information}

This research received no specific grant from any funding agency in the public, commercial or not-for-profit sectors.

\section{Data availability statement}

Data sharing is not applicable to this article as no new data were created or analysed in this study.

\section{Disclaimer}

The views and opinions expressed in this article are those of the authors and do not necessarily reflect the official policy or position of any affiliated agency of the authors.

\section{References}

Adebayo, R.I., 2010, 'Ethno-religious crises and the challenges of sustainable development in Nigeria', Journal of Sustainable Development in Africa 12(4), 213-225.

Aghedo, I., 2014, 'Old wine in a new bottle: Ideological and operational linkages between Maitatsine and Boko Haram revolts in Nigeria', African Security 7(4), 229-250. https://doi.org/10.1080/19392206.2014.977169
Ajayi, F., 2009, The effect of religion on the political process, iUniverse, New York, NY.

Alegbeleye, G.I., 2014, 'Ethno-religious crisis and socio-economic development in Nigeria: Issues, challenges and the way forward', Journal of Policy and Development Studies 9(1), 139-148. https://doi.org/10.12816/0011188

Aliyu, K., Ikedinma, H. \& Akinwande, A., 2018, 'Assessment of the effect of farmersherdsmen conflicts on national integration in Nigeria', International Journal of Humanities and Social Science 8(10), 118-128. https://doi.org/10.30845/ijhss. v8n10p13

Amnesty International, 2018, Nigeria: Government failures fuel escalating conflict between farmers and herders as death toll nears 4,000, viewed 20 February 2020, from https://www.amnesty.org/en/latest/news/2018/12/nigeria-governmentfailures-fuel-escalating-conflict-between-farmers-and-herders-as-death-tollnears-4000/.

Best, S.G. \& Rakodi, C., 2011, Religions and development research programme: Violent conflict and its aftermath in Jos and Kano, Nigeria: What is the role of religion? viewed 18 March 2020, from http://epapers.bham.ac.uk/1653/1/ BestRakodiViolence.pdf.

Canci, H. \& Odukoya, O.A., 2016, 'Ethnic and religious crises in Nigeria: A specific analysis upon identities (1999-2013)', African Journal on Conflict Resolution 16(1), 87-110.

Edewor, P.A., Aluko, Y.A. \& Folarin, S.F., 2014, 'Managing ethnic and cultural diversity for national integration in Nigeria', Developing Country Studies 4(6), 70-76.

Ekeopara, C.A. \& Ekpenyong, O.E., 2016, 'African traditional religion and national development in Nigeria', Research on Humanities and Social Sciences 6(22), 19-28.

Eyoboka, S., 2020, 'Nigerians react to Leah Sharibu's motherhood', Vanguard, viewed 28 February 2020, from https://www.vanguardngr.com/2020/01/nigerians-reactto-leah-sharibus-motherhood/.

Faleye, O., 2013, 'Religious corruption: A dilemma of the Nigerian State', Journal of Sustainable Development in Africa 15(1), 170-185.

Femi Bolaji, J., 2019, 'Taraba killings: We can't take this anymore!', Vanguard, viewed 26 March 2020, from https://www.vanguardngr.com/2019/06/taraba-killings-wecant-take-this-anymore/.

Global Terrorism Index, 2019, 'Global terrorism index 2019: Measuring the impact of terrorism', Institute for Economics \& Peace, viewed 23 April 2020, from http:// visionofhumanity.org/app/uploads/2019/11/GTI-2019web.pdf.

Hassan, I., 2020, 'Southern Kaduna decries attacks on communities', Vanguard, viewed 26 March 2020, from https://www.vanguardngr.com/2020/03/southernkaduna-decries-attacks-on-communities/.

Herbert, D., 2017, 'Religion and civil society: Rethinking public religion in the contemporary world', Religion, Culture and Society Series, Taylor \& Francis, London and New York, NY.

Idowu, J., 2015, 'Resolving and preventing the spread of Boko Haram Insurgency in Nigeria', Ibadan Journal of Peace and Development 2(3), 77-100. https://doi. org/10.4314/gjss.v14i1.4

Ikenga-Metuh, E., 1994, 'Two decades of religious conflicts in Nigeria: A recipe for peace', Bulletin of Ecumenical Theology 6(1), 69-93.

Ituma, E.A., Ukeachusim, C.P. \& Ilechukwu, L., 2013, 'The role of religion in combating corruption and management of religious crisis in Nigeria', International Journal of Theology \& Reformed Tradition 5, 30-47.

Johnson, D., 2020, 'Suspected herdsmen kill father, son, one other in Ondo farm' Vanguard, viewed 23 April 2020, from https://www.vanguardngr.com/2020/04/ suspected-herdsmen-kill-father-son-one-other-in-ondo-farm/.

Mamah, E., Ndujihe, C., Nkwopara, C. \& Ozor, C., 2016, 'Bloodbath in Enugu as Fulani herdsmen kill 40', Vanguard, viewed 05 March 2020, from https://www. vanguardngr.com/2016/04/bloodbath-enugu-fulani-herdsmen-kill-40/.

National Bureau of Statistics, 2020, Labour markets, unemployment rate, viewed 23 April 2020, from https://nigerianstat.gov.ng/uploads/LaborQ32018.png.

Ndujihe, C., 2018, 'Benue attacks: Can IGP, defence minister check out these dates?', Vanguard, viewed 04 March 2020, from https://www.vanguardngr.com/2018/02/ benue-attacks-can-igp-defence-minister-check-dates/.

NziokiMunyao, J., MuemaMwania, J. \& Mwinzi, J., 2017, 'Factors influencing the choice of Christian Religious Education by secondary school students in Makuen sub-county, Makueni County-Kenya', International Journal of Education and Research 5(12), 31-44.

Odunsi, W., 2020, 'Boko Haram executes CAN chairman Andimi', Daily Post, viewed 13 February 2020, from https://dailypost.ng/2020/01/21/breaking-boko-haramexecutes-can-chairman-lawan-andimi/.

Okafor, C. \& Neme, S., 2020, '14 feared killed by Fulani Herdsmen in Delta community', TheGuardian, viewed 06 March 2020, from https://guardian.ng/news/14-fearedkilled-by-fulani-herdsmen-in-delta-community/.

Okwueze, M.I., 2003, Ethics religion and society: Biblical traditional of contemporary perspectives, Prize Publishers, Nsukka.

Oladipo, J., 2000, 'The role of the church in poverty alleviation in Africa', Transformation: An International Journal of Holistic Mission Studies 17(4), 146-152. https://doi. org/10.1177/026537880001700408

Omotosho, A.O., 2003, 'Religious violence in Nigeria - The causes and solutions: An Islamic perspective', Swedish Missiological Theme 16, 15-31.

Onah, N.G., Diara, B.C. \& Uroko, F.C., 2017, 'Ethno-religious conflicts in Nigeria: Implications on women', Mediterranean Journal of Social Sciences 8(5), 61-68. https://doi.org/10.2478/mjss-2018-0097

Osunyikanmi, P.O. \& Sapele, F.F., 2019, 'The role of government and religion in combating violence in Nigeria: The Niger Delta experience', Advances in Multidisciplinary \& Scientific Research Journal Publication 7(1), 31-36. https:// doi.org/10.22624/aims/humanities/v7n1p4 
Polachek, S.W. \& Sevastianova, D., 2012, 'Does conflict disrupt growth? Evidence of the relationship between political instability and national economic performance', https://doi.org/10.1080/09638191003749783

Ray, D. \& Esteban, J., 2017, 'Conflict and development', Annual Review of Economics 9(1), 263-293. https://doi.org/10.1146/annurev-economics-061109-080205
Salawu, B., 2010, 'Ethno-religious conflicts in Nigeria: Causal analysis and proposals for new management strategies', European Journal of Social Sciences 13(3), 345-353.

Tukur, S., 2018, 'Why I signed new executive order to fight corruption - Buhari', Premiumtimes, viewed 10 February 2020, from https://www.premiumtimesng. com/news/top-news/275145-why-i-signed-new-executive-order-to-fightcorruption-buhari.html. 